\title{
Corporate Governance and the Growing Role of Women in the Boardroom
}

\author{
Kevin Campbell and Leszek Bohdanowicz \\ Chapter 6 \\ Transforming Governance: New Values, New Systems in the New Business Environment, \\ Farnham, Surrey: Gower, October 2015.
}

\section{Introduction}

The presence of women on corporate boards and their impact on board effectiveness is now one of the most contentious issues in corporate governance. This arises from the relatively low, though increasing, number of female directors on boards around the world, despite an increasing number of well-qualified women in the labour force. Although gender discrimination is unlawful, there is a perception that many women still encounter invisible barriers to promotion, in effect facing a 'glass ceiling' where they can see, but not reach, high-level corporate positions. Companies that do not appoint women to their boards run the risk of suffering inferior performance as they fail to make use of the intellectual and social capital that women offer.

We describe a theoretical framework that can be used to understand the impact of board gender diversity on board effectiveness and firm performance, and highlight four key theories: agency theory, resource dependency theory, gender role theory and upper echelons theory. We also review the arguments in the corporate governance literature for greater female boardroom representation. We begin with the ethical case and then consider the business case. The former is concerned with the principle that there should be no discrimination in the workplace, while the latter focuses on the benefits that women bring to the boardroom by drawing from a broader talent pool of directors. We also review the possible costs associated with an increase in the gender balance of boards. 
The main public policy to improve the gender diversity of boards is the gender quota, which 12 European countries have introduced on either a voluntary or mandatory basis. Belgium, France, Italy, the Netherlands and Norway now have mandatory quotas ranging from 30 to 40 per cent female membership, while Austria, Denmark, Finland, Germany, Greece, Slovenia and Spain have voluntary quotas. The European Commission has proposed legislation with the objective of achieving a 40 per cent presence of the under-represented gender in non-executive board-member positions in publicly listed companies (European Commission, 2012). In the UK, the approach to board-level gender diversity has been less prescriptive. The Davies Report (2011) on Women on Boards focused attention on the paucity of female directors and included a recommendation that 25 per cent of board members should be female by 2015. However, when amended in 2012, the UK Corporate Governance Code did not include this target, only requiring listed companies to establish a policy concerning boardroom diversity, including measurable objectives for implementing the policy. Despite these various European initiatives, the proportion of women on European boards is still only 17 per cent, with women more likely to fill the role of independent, non-executive directors rather than executive positions (Heidrick and Struggles, 2013).

The chapter concludes with an evaluation of the evidence, both positive and negative, concerning the effectiveness of greater female boardroom participation in improving business performance and highlights the methodological issues that need to be tackled in order to better understand the nature of the relationship between board gender composition and financial performance.

\section{Women in the Boardroom: The Theoretical Framework}

Theories that facilitate understanding of the impact of board gender diversity on board effectiveness and firm performance can be found in both the economics literature and the management literature. From the former, agency theory can be used to understand the monitoring role of boards, while from 
the management literature, resource dependency theory, gender role theory and upper echelons theory can all inform understanding of the gender-specific attributes of boardroom roles.

Agency Theory

Agency theory is concerned with the inherent conflicts between the interests of agents (directors and senior managers) and the interests of the principals (owners) whose capital is at risk. Boards perform an important dual role as both monitors and advisers (Adams and Ferreira, 2007). There is evidence that female board members are likely to take a more active role compared to their male counterparts (Virtanen, 2012). Women are also more likely to ask questions in the boardroom (Bilimoria and Wheeler, 2000), to debate issues (Ingley and Van der Walt, 2005), to exhibit participative leadership and collaboration skills (Eagly and Johnson, 1990) and to apply higher ethical standards (Pan and Sparks, 2012). The ability of women to influence board decisions seems to increase with their numbers, particularly for boards with more than one woman (Fondas and Sassalos, 2000) or three women (Konrad and Kramer, 2006; Torchia et al., 2011). There is also evidence that female board members are better prepared for meetings (Pathan and Faff, 2013) and that they attend more board meetings (Adams and Ferreira, 2009). The weight of evidence from these studies suggests that female directors can enhance board monitoring and thereby improve firm performance.

\section{Resource Dependency Theory}

Resource dependency theory considers how external resources affect firm behaviour (Pfeffer and Salancik, 1978). In this context, directors can provide access to valuable knowledge and expertise through their social networks and their relationships with key outsiders such as regulators and financiers (Hillman et al., 2002). When considering directors as resource providers, gender diversity becomes important as women may bring unique and valuable resources and relationships to their boards. There is evidence that female managers generally have more diverse social networks (Ibarra, 1992, 1993). There is also evidence that women may understand certain markets and consumers better than men (Arfken et al., 2004). Research also suggests that female directors are more likely to have non-business backgrounds and thus a diversity of perspectives that can enhance overall creativity and innovation in problem solving (Hillman et al., 2002; Singh et al., 2008). 


\section{Gender Role Theory}

Gender role theory suggests that an individual's gender is an important determinant of his or her behaviour and influence over others (Eagly, 1987). The theory is based on the premise that the behaviour of men and women is assessed in terms of societal expectations of how their gender ought to behave. Those who use tactics aligned to their gender tend to be perceived better by others (Eagly et al., 1995). Gender role theory describes how men and women have normatively prescribed behaviour with respect to the way in which they communicate with and influence others. For example, women are expected to display more feminine characteristics such as sympathy, while men are expected to be more assertive (Eagly, 1987). Another gender role associated with women is flexibility, with the notion that women are better at managing ambiguous situations (Rosener, 1995). Gender roles are relevant to boardroom dynamics, as directors must use communication tactics that are effective in influencing other board members. Gender roles are also particularly important in male-dominated realms such as the board of directors where esteem is crucial to effectiveness (Forbes and Milliken, 1999). The gender role theory literature contains ideas that help explain why women are underrepresented in business as well as arguments suggesting that greater board gender diversity can improve firm performance.

\section{Upper Echelons Theory}

Upper echelons theory describes how the behaviour of executives may be explained by personal experiences and values that determine their cognitive frames when making decisions and thus firm outcomes (Hambrick and Mason, 1984; Hambrick, 2007). Because men and women may differ in their cognitive frames, board gender diversity is likely to influence firm performance (Carpenter, 2002). Female directors are likely to bring different cognitive frames to a board due to differences in their experiences and knowledge, thus expanding the available pool of knowledge. For example, female directors tend to have more university degrees than male directors and to have more advanced degrees (Carter et al., 2010; Hillman et al., 2000). Female directors bring different experiences and knowledge by virtue of the route they have taken to the boardroom: they are less likely to have been CEOs and are more likely to come from non-business backgrounds (Hillman et al., 2002; Singh et al., 2008). 
Female directors may also have different cognitive frames by virtue of their roles and experiences outside of the workplace. Women have more influence over household purchasing decisions (Phipps and Burton, 1998) and so they are likely to enhance boardroom understanding of consumer markets (Bilimoria and Wheeler, 2000; Carter et al., 2003). In addition, female directors have a more diverse set of non-work activities and a greater interest in philanthropy and community service, which are likely to benefit firms' multiple stakeholders (Groysberg and Bell, 2013). In sum, the upper echelons theory literature provides a range of arguments relating to the female cognitive frame which suggest that greater female board representation may improve the quality of boardroom discussion and decision making, which ultimately feeds through into stronger financial performance.

\section{Arguments for Greater Female Boardroom Representation}

The arguments for greater female representation in the boardroom are sourced from the foregoing theoretical framework and thus draw upon ideas that can be found in agency theory, resource dependency theory, gender role theory and upper echelons theory. This multi-theoretical lens is a powerful tool with which to illuminate the business case for more women at the boardroom level, which is based on the additional economic value that their presence can create. These theories also assist in understanding the reasons why women are under-represented at the boardroom level; however, the ethical case for more female directors itself rests upon the principle of social justice, namely that the appointment of women to boards is justified solely on the normative basis of equality of opportunity and non-discrimination. In the interests of balance, we also consider the additional costs that may arise from greater board gender diversity.

\section{The Ethical Case for Greater Female Board Representation}

The ethical case for greater female representation in the boardroom is based on the proposition that it is immoral for women to be excluded from corporate boards on the grounds of gender and that increasing gender diversity achieves a more equitable outcome for society. There are two major causes of discrimination against women in business that result in their reduced presence on company boards: the 'double burden' syndrome and the 'glass ceiling'. In most societies, women are at the centre of family life and often have to combine work with household responsibilities, and thus face a 'double burden' (McKinsey, 2007). Due to the need for career breaks because of childbirth and the subsequent 
care of children, women often face a natural handicap compared to men in terms of workplace advancement.

The 'glass ceiling' metaphor was coined by the Wall Street Journal in a 1986 special report and refers to an invisible barrier that prevents women from reaching top positions in business (Wall Street Journal, 1986). It is the most frequently cited discriminatory barrier facing women. The metaphor stems primarily from the historically determined perception of the roles of women in society (Bilimoria and Piderit, 1994). In the past, women were perceived to have lower ambitions, selfconfidence and assertiveness relative to men, and to possess poor leadership skills (Powell, 1999). They are therefore confronted with a 'glass ceiling' that prevents them from reaching the visible, but unattainable, upper echelons of the corporate world.

In the second half of the twentieth century, most countries gradually introduced gender equality into all areas of life, but as late as in the 1960s in the US, women were still expected to primarily take care of their families. Typical occupations in which women were prevalent included nursing, teaching and various forms of volunteering, which explains why women play a major role in the public sector to this day. When women started to enter the business world, they initially took positions requiring abilities that corresponded to their previous occupations and roles in society. Thus, they mostly supported the work of others (for example, as secretaries) or held positions in human resources or communications (Rosener, 1990).

Despite progress being made in terms of combating discrimination and challenging stereotypes about the perceived roles of women in society, the glass ceiling seems to be deeply rooted in the culture of many organisations. In a questionnaire survey conducted by McKinsey (2007), 27 per cent of women admitted to being discriminated against in the workplace. Interestingly, women who hold corporate managerial positions or senior political office sometimes reinforce the 'glass ceiling'. Sometimes this phenomenon takes an extreme form, described by Terjesen and Singh (2008) as the 'queen bee' syndrome, whereby older women in positions of power resent younger colleagues and deliberately make it difficult for them to achieve their career objectives, preferring to promote and surround themselves with men. An often-cited example is the former UK Prime Minister Margaret Thatcher, who is alleged to have done little to promote other women while in office (Smith, 2000). 
Various initiatives to promote gender equality are gradually helping women to break through the 'glass ceiling', but it is arguably just as important to overcome the 'double burden' syndrome arising from the central role played by women in the family. Women's roles in this respect differ across countries depending on cultural factors, economic development and infrastructure (for example, the availability of social services and tax policy concerning working mothers). As a result, the presence of women on boards varies across countries according to these differing social, political and economic factors. Countries with more women in senior management roles and smaller gender pay gaps tend to have more diverse corporate boards (Terjesen and Singh, 2008). However, as a result of their family responsibilities, women face greater difficulties reconciling their professional and domestic lives, which often leads to limited professional development prospects or the necessity of trading off family life against careers. Due to the latter choice, women often exhibit smaller professional ambitions and so many more women than men voluntarily leave their careers to devote themselves to their families (Hewlett and Luce, 2005).

Due to the 'double burden' syndrome and its associated choices, women at higher levels in companies often have fewer children or no children at all. Hewlett (2002) reports that as many as 49 per cent of women aged $41-55$ in the highest paid category (earning over $\$ 100,000$ a year) were childless. Similarly, McKinsey (2007) reports that 54 per cent of women holding middle and top management positions in European and US companies did not have children.

It is possible that social pressure to increase the participation of women on company boards may give rise to token appointments, whereby women are chosen solely to represent their gender (Kanter, 1977). For instance, Carver (2002) suggests that companies have a tendency to exhibit 'tokenism' in their board appointments to legitimise the composition of the board. In this case, women are treated first of all as representatives of their gender, with their role as board members coming second. The opinions of token board members do not always get the same treatment as that given to those of male members, and so the benefits of board diversity are lost (Sheridan and Milgate, 2005).

While one woman on a board may be only a token appointment and two may be insufficient to change a firm's policies, three may constitute the 'critical mass' necessary to make a noticeable impact (Rosener, 1990). This view is supported by Erkut et al. (2009), who find that women on boards with 
three or more women members are more likely to feel comfortable raising issues and taking an active role. Brown et al. (2002) find that boards with three or more female members behave differently from those consisting exclusively of men and are more likely to have conflict-of-interest guidelines and formal codes of conduct.

The tokenistic approach to women on corporate boards is supported by Farrel and Hersch (2005), who find that the likelihood of appointing women is negatively correlated with the number of directors appointed in previous years, and that this likelihood increases if a woman leaves the board. Their study suggests that in many cases, it is gender rather than competence that is decisive in the appointment of female directors.

Social pressure to appoint women to corporate boards may also contribute to negative perceptions of female boardroom candidates. Ryan and Haslam $(2005,2007)$ argue that women who break through the 'glass ceiling' to the boardroom are often appointed by companies that find themselves in a difficult financial situation and are thus confronted with a 'glass cliff' effect, given the heightened risk of failure. If and when that failure occurs, female directors are often singled out for criticism, despite financial problems pre-dating their appointment.

While the case for more women on boards is most often based on the business advantages associated with greater female participation in decision making, the ethical case suggests that gender should not be a reason for discrimination and that firms should regard greater female representation not as a means to an end, but as a desirable end in itself (Brammer et al., 2007). In fact, there is evidence that having more women in the boardroom enhances corporate ethical behaviour. For example, the presence of women on the board is associated with higher earnings quality (Gul et al., 2011) and better oversight of management reporting that reduces earnings management (Srinidhi et al., 2011).

\section{The Business Case for Greater Female Board Representation}

The business case for greater female board representation is based on the premise that women provide an extra dimension to boardroom dynamics that enhances the operation of the board and its governance, which should ultimately be reflected in improved financial performance. The business case revolves around four potential benefits provided by female directors: improved boardroom 
creativity and decision making; the provision of access to the widest talent pool; increased responsiveness to the marketplace; and the achievement of better corporate governance. We consider each of these in turn.

A substantial body of research has shown that groups that are more diverse in terms of age, gender or education behave differently from uniform groups (Erhardt et al., 2003). For example, diverse groups do much better in a turbulent environment, as exemplified by the recent global financial crisis, where the need for more knowledge and information was critical (Rost and Osterloh, 2010). Members of homogeneous groups tend to communicate with each other more frequently and reach a consensus more often. Such groups face a lower risk of conflict and tend to make decisions faster (Earley and Mosakowski, 2000; Lau and Murnighan, 1998). More women on the board can enhance business performance through greater creativity of thought in the decision-making process and the provision of a wider range of perspectives (Wiersema and Bantel, 1992). A more gender diverse board is therefore less likely to suffer from 'group think', which typically manifests itself as a sense of infallibility, excessive optimism and disregard for the opinions of persons outside the group (Watson et al., 1993). Members of boards that suffer from 'group think' often practise self-censorship as they are reluctant to express opinions that might put them at risk of criticism from other board members and, as a consequence, alienation. The impact made by women appears to improve once a threshold level of women in leadership positions is reached, with a critical mass of 30 per cent or more women at board level or in senior management producing the best financial results (McKinsey, 2007).

It is a truism to say that corporate self-interest is served by appointing the best candidates to the boardroom, so choices should logically be made from the widest talent pool irrespective of gender. In many countries, women form an increasing proportion of the labour force and increasingly they are more highly educated than men. In North America, around six out of every 10 university graduates is a woman, with the same trend evident in many emerging economies (Maitland, 2010). More than half of the students graduating from Europe's universities are women (European Commission, 2012). Given the increasing educational attainment of women, it is natural to expect their representation in boardrooms to increase and business performance to improve as a result. 
All corporate boards comprise individuals with varying competencies who, in aggregate, constitute the board's social and intellectual capital. By appointing women to corporate boards, shareholders can not only make better use of the available intellectual capital, but can also add value because of the high educational attainment of women (Daily et al., 1999; Carpenter and Westphal, 2001). This capital consists not only of the knowledge contributed by women, but also the value produced by them in the process of strategic decision making. The diversity in outlook provided by women may help enhance board decision making by increasing the number of alternatives considered, the quality of ideas discussed and provoking livelier boardroom discussions (Letendre, 2004). Boards with female members who have different values are also more likely to consider counter-arguments and to question conventional wisdom (Bilimoria and Huse, 1997; Huse and Solberg, 2006). Based on survey data from Norwegian firms, Nielsen and Huse (2010) find that female directors influence board strategic involvement through their contribution to board decision making, which in turn depends on their professional experiences and different values.

According to recent estimates, women control about 70 per cent of global consumer spending (O'Donnell and Kennedy, 2011). More women in the boardroom can therefore provide a better understanding of consumers' choices and help create products and services that are more responsive to their needs and preferences. This knowledge varies across industry sectors and is reflected in a UK study showing that the highest rates of female directors are found in those sectors that address their products to the final customer, the so-called 'consumer-facing' sectors - retail, utilities, media and banking - and are lower in those sectors that do not (Brammer et al., 2007).

The presence of more women in the boardroom can enhance corporate governance by increasing the independence of the board and thus sharpening the scrutiny of executive decision making. Farrell and Hersch (2005) argue that since women historically have limited experience of executive roles, it is reasonable to believe that they will improve board independence, and they document that most new female directors appointed to the boards of a sample of US firms from 1990 to 1999 are outsiders. Adams and Ferreira (2009) suggest that female directors are more likely to exhibit independence of thought because they are not members of 'old boys' networks'. Their analysis of a sample of US firms covering the period 1996 to 2003 finds that female directors have better 
attendance records at board meetings than male directors, that male directors have fewer attendance problems the more gender-diverse the board is, and that women are more likely to join monitoringrelated board committees. They also find that more gender diverse boards are more likely to hold CEOs to account, given that CEO turnover is more sensitive to stock return performance in firms with relatively more women on boards. These results all suggest that more gender-diverse boards allocate greater effort to monitoring.

\section{The Possible Costs of Greater Female Board Representation}

While the business case for greater board gender diversity is based on the potential benefits arising from the presence of women in the boardroom, this presence also has potential costs (Adams and Ferreira, 2009). Because the proportion of women in top executive positions is small, albeit growing, employing more female directors may produce a board with a low average age that lacks experience. Furthermore, because qualified candidates are likely to be in short supply, they are likely to accumulate multiple board seats, and such 'busy' directors are arguably less effective than less busy ones. Ahern and Dittmar (2012) report the impact of the new law introduced by Norway in 2003 requiring that 40 per cent of listed company directors be women by 2008 . They observe that the average proportion of female directors in listed firms was about 10 per cent when the gender balance law was passed. During the next five years, firms complying with the 40 per cent quota replaced about one-third of their male directors with women. The number of female directorships increased by $260 \%$ (from 165 to 592 seats), while the number of male directorships dropped by $38 \%$ (from 1,516 to 938 seats). Crucially, they find that the new law led to younger and less experienced boards and a drop in market performance.

Further evidence on the impact of the 40 per cent board gender quota in Norway is provided by Bøhren and Staubo (2013), who find that the recruitment of female directors with multiple seats was not a widespread strategy to comply with the quota. They suggest that a possible reason for this is that shareholders fear that busy directors may easily become overstretched and therefore have less value or, alternatively, that the pool of females who could potentially hold multiple directorships was so small that this source of recruitment did not matter much. A related study by Bøhren and Staubo (2014) finds that the introduction of the 40 per cent quota in Norway law led to a reduction in board 
independence, which is a more widespread property among female director candidates than among males. They also report that approximately half of the Norwegian firms exposed to the 40 per cent quota changed their organisational form to avoid the legal requirement to adopt the quota and that some firms consciously avoided adopting the organisational form exposed to the new law.

Another potential cost associated with increasing gender diversity is the possibility of communication breakdowns between top executives and minority outside directors. As Adams and Ferreira (2007) point out, outside directors rely on executives to gain access to firm-specific information. Executives may perceive female directors as sharing different values and espousing dissimilar views. The reluctance of executives to share information with minority outside directors could compromise board effectiveness.

Increasing board gender diversity may also result in the recruitment of directors more interested in pushing their own personal agenda than in safeguarding the interests of shareholders. For example, according to some studies, women pay greater attention to the social aspects of business and are more willing than men to use company resources to support charities and various groups of stakeholders, which is often inconsistent with shareholders' expectations (Ibrahim and Angelidis, 1994; Williams, 2003). This may be related to the different experiences of women, whose involvement in non-profit projects is typically more substantial than that of men (Wang and Coffey, 1992). Charitable activities may turn out to be beneficial for companies in the long term, but this is difficult to verify empirically, even though such involvement may improve a firm's image and boost employee morale.

\section{Women on the Board and Firm Financial Performance: Evidence}

We now turn our attention to the empirical studies that investigate the relationship between female boardroom representation and firm financial performance. These studies generally test for a direct relationship between the presence, or proportion, of female directors and financial performance. The measures of firm performance in these studies include both accounting-based measures such as return on assets (ROA), return on equity (ROE), employee productivity and return on invested capital (ROIC), and market-based measures such as the market-to-book ratio, Tobin's q and shareholder 
returns. The evidence is mixed. Some find a positive relationship (for example, Carter et al., 2003; Erhardt et al., 2003; Campbell and Minguez-Vera, 2008, 2010), while others find either a negative relationship (for example, Bøhren and Strøm, 2010; Minguez-Vera and Martin, 2011) or an insignificant relationship (for example, Shrader et al., 1997; Rose, 2007; Carter et al., 2010). In order to better understand the reasons for these conflicting results, we briefly explain the methodological challenges involved in testing the impact of board gender diversity and firm performance, and we conclude with the lessons that can be drawn from the results of a comprehensive meta-analysis by Post and Byron (2014).

A frequently cited study documenting a positive relationship between the gender and ethnic diversity of the board and corporate performance, as proxied by Tobin's q, is that of Carter et al. (2003). A further study by Carter et al. (2010) reports additional evidence consistent with a positive impact of gender diversity on the market value of firms. Erhardt et al. (2003) provide evidence that board diversity is positively correlated with accounting measures of performance. Adams and Ferreira (2009) find an initially positive relationship between financial performance, measured by both Tobin's $\mathrm{q}$ and ROA, and the fraction of women on boards, controlling for other corporate governance variables. The authors then go on to address the important issue of possible endogeneity in the relationship between firm performance and board gender. This may arise from reverse causality (rather than female directors improving firm performance, better-performing firms may simple attract more female directors) or from omitted variable bias (the possibility that there is an underlying missing variable that influences both board gender diversity and firm performance). For example, gender diversity could be correlated with omitted firm-specific variables such as corporate culture such that more progressive firms may perform better and also have more female directors. When they include firm fixed effects to take account of the possibility of an omitted variable, the sign of the estimated coefficient on the fraction of female directors in their regression model changes from positive to negative and is statistically significant, albeit at the 10 per cent level. This result casts doubt on a causal interpretation of the widely documented positive relationship between firm performance and women on boards. Since the results of regression models that use fixed effects do not establish the direction of causality, Adams and Ferreira (2009) also use an instrumental variable (IV) approach, 
employing the number of male director connections to female directors on other boards as an instrument for the fraction of women on boards. Once again, they find that the impact of an increase in the fraction of female directors on both Tobin's q and ROA is negative.

The key message from the work of Adams and Ferreira (2009) is that some firms are likely to benefit from more gender diversity, while others are not. Based on attendance records, they argue that female directors are more likely to be tough monitors. However, because an excessive emphasis on monitoring can sometimes be counterproductive, additional monitoring can reduce performance in firms that are otherwise well governed.

An alternative method for determining the direction of causality is to look for a so-called natural experiment - an exogenous change in the environment that forces firms to alter the composition of their boards. In this regard, Ahern and Dittmar (2009) exploit the introduction of the mandatory 40 per cent female board quota in Norway. They find that firms that adjust to this new level suffer an abnormal decline in market value.

Most of the research on the relationship between board gender and firm performance is focused on a single country, which has led to calls for more multi-country studies to ascertain the extent to which results may be influenced by differences in social and cultural factors across countries (Terjesen and Singh 2008; Grosvold and Brammer, 2010). These calls are addressed by Terjesen et al. (2015), who use data from 3,876 public firms in 47 countries and find that firms with more female directors have higher market-based (Tobin's q) and accounting-based (ROA) performance, controlling for a wide set of corporate governance mechanisms and for endogeneity. Acknowledging the fact that the corporate governance literature has focused more on boards' independence than their gender balance, the authors also address how the relationship between board independence and firm performance is moderated by board gender. Interestingly, they find that external independent directors do not contribute to firm performance unless the board is gender-diversified, suggesting that gender diversity might act as a substitute for board independence. From this they conclude that corporate governance codes worldwide should give at least the same importance to gender diversity as they give to the structure of board independence. 
The lack of consistent findings in prior studies may be due to differences in measures of firm performance and control variables as well as differences in methodology. A useful tool that creates a general impression of the weight of evidence by systematically combining the results of prior studies is meta-analysis. In an attempt to reconcile the conflicting results in the literature, Post and Byron (2014) perform a meta-analysis of the results from 140 studies representing roughly 90,070 firms in 35 countries on five continents. They find that female board representation is positively related to accounting returns and that the relationship is more positive in countries with stronger shareholder protections, perhaps because shareholder protections motivate boards to use the different knowledge, experience and values that each member brings to the board. The analysis also reveals that while there is a near-zero relationship between female board representation and market-based performance, the relationship is positive in countries with greater gender parity and negative in countries with low gender parity. The authors believe this may be a result of societal gender differences in human capital influencing investors' evaluations of the future earning potential of firms that have more female directors. Of particular note, according to the authors, is the fact that the presence of women on the board is positively related to boards' two primary responsibilities, namely monitoring and strategy involvement. This suggests that the influence of female directors on firm performance may operate, at least in part, by increasing attention on directors' legally mandated board responsibilities.

A limitation of the meta-analysis conducted by Post and Byron (2014) is that it is not possible to account for possible endogeneity caused by reverse causality or omitted variables in the relationship between female board representation and firm performance. Those conducting primary studies may employ strategies not available to meta-analysts, such as lagging dependent variables and two-stage least squares modelling. However, the authors made two attempts to uncover the possible influence of endogeneity. First, they explored whether study design (cross-sectional or lagged) moderated the relationship between female board representation and firm performance, and found no significant difference. Second, they explored whether they could eliminate the possibility that an omitted variable (board independence) was a source of endogeneity, and again found no significant difference in respect of this variable. The authors are careful, however, not to make any claims about causality, 
noting that almost none of the studies in their meta-analysis addressed possible endogeneity, and they urge future researchers to address this concern.

\section{Conclusion}

We have outlined the arguments for greater female representation in the boardroom, drawing upon ideas from agency theory, resource dependency theory, gender role theory and upper echelons theory. This theoretical framework provides the tools to understand the business case, as well as the reasons for the under-representation of women at board level, and the additional costs that may arise from greater board gender diversity. As greater female presence in the boardroom will give rise to benefits and costs, the impact on boardroom efficiency and financial performance will ultimately depend upon the relative balance of each, which is likely to vary across firms.

The evidence from the empirical literature on the relationship between board gender diversity and firm performance is inconclusive, in large part because very few studies investigate the direction of causality. Despite this, the global legislative agenda concerning board diversity is very much focused on the issue of gender, with 16 national corporate governance codes and 13 national quotas addressing boards' gender structure (Terjesen et al., 2015). Unpicking the relationship between gender and other corporate governance variables offers the promise of enhancing understanding of how board gender composition influences firm performance. The recent finding that board independence is secondary when gender diversity is not addressed (Terjesen et al., 2015) suggests that board gender diversity is an important corporate governance issue that is likely to remain at the top of the policy agenda. A promising avenue for future research is the investigation other types of board diversity (such as educational background, ethnicity and age). The creation of a board diversity index by Anderson et al. (2011) is an example of one approach that could meaningfully extend knowledge of how gender interacts with other director characteristics. 


\section{References}

Adams, R.B. and Ferreira, D. (2007). A Theory of Friendly Boards. Journal of Finance, 62(1), pp. $217-50$.

(2009). Women in the Boardroom and Their Impact on Governance and Performance. Journal of Financial Economics, 94, pp. 291-309.

Ahern, K.R. and Dittmar, A. (2012). The Changing of the Boards: The Impact on Firm Valuation of Mandated Female Board Representation. Quarterly Journal of Economics, 127(1), pp. 137-97.

Anderson, R.C., Reeb, D., Upadhyay, A. and Zhao, W. (2011). The Economics of Director Heterogeneity. Financial Management, 40(1), pp. 5-38.

Arfken, D.E., Bellar, S.L. and Helms, M.M. (2004). The Ultimate Glass Ceiling Revisited: The Presence of Women on Corporate Boards. Journal of Business Ethics, 50(2), pp. 177-86.

Bilimoria, D. and Huse, M. (1997). A Qualitative Comparison of the Coardroom Experiences of US and Norwegian Women Corporate Directors. International Review of Women and Leadership, $3(2)$, pp. 63-73.

Bilimoria, D. and Piderit, S.K. (1994). Board Committee Membership: Effects of Sex-Based Bias, Academy of Management Journal, 37(6), pp. 1453-77.

Bilimoria, D. and Wheeler, J.V. (2000). Women Corporate Directors: Current Research and Future Directions. In M.J. Davidson and J.D. Burke (eds), Women in Management: Current Research Issues, Volume II. London: Paul Chapman Publishers, pp. 138-63.

Bøhren, Ø. and Strøm, R.Ø. (2010). Governance and Politics: Regulating Independence and Diversity in the Boardroom. Journal of Business Finance \& Accounting, 37, pp. 1281-308.

Bøhren, Ø. and Staubo, S. (2013). Female Directors and Board Independence: Evidence from Boards with Mandatory Gender Balance. Working Paper, BI Norwegian Business School.

. (2014). Does Mandatory Gender Balance Work? Changing Organizational Form to Avoid Board Upheaval. Journal of Corporate Finance, 28, pp. 152-68.

Brammer, S.J., Millington, A. and Pavelin, S. (2007). Gender and Ethnic Diversity among UK Corporate Boards. Corporate Governance: An International Review, 15(2), pp. 393-403.

Brown D., Brown, D. and Anastasopoulos, V. (2002). Women on Boards: Not Just the Right Thing ... But the 'Bright' Thing. Report 341-02, Conference Board of Canada, Ottawa. 
Campbell, K. and Minguez-Vera, A. (2008). Gender Diversity in the Boardroom and Firm Financial Performance. Journal of Business Ethics, 83, pp. 435-51.

. (2010). Female Board Appointments and Firm Valuation: Short and Long-Term Effects. Journal of Management and Governance, 14, pp. 37-59.

Carpenter, M.A. (2002). The Implications of Strategy and Social Context for the Relationship between Top Management Team Heterogeneity and Firm Performance. Strategic Management Journal, 23(3), pp. 275-84.

Carpenter, M.A. and Westphal, J.D. (2001). The Strategic Context of External Network Ties: Examining the Impact of Director Appointments on Board Involvement in Strategic Decision Making. Academy of Management Journal, 44(4), pp. 639-60.

Carter, D.A., D’Souza, F., Simkins, B.J. and Simpson, W.G. (2010). The Gender and Ethnic Diversity of US Boards and Board Committees and Firm Financial Performance. Corporate Governance: An International Review, 18, pp. 396-414.

Carter, D.A., Simkins, B.J. and Simpson, W.G. (2003). Corporate Governance, Board Diversity and Firm Value. Financial Review, 38, pp. 33-53.

Carver, J. (2002). On Board Leadership. New York: Jossey-Bass.

Daily, C.M., Certo, S.T. and Dalton, D.R. (1999). A Decade of Corporate Women: Some Progress in the Boardroom, None in the Executive Suite. Strategic Management Journal, 20(1), pp. 93-100.

Davies Report (2011). Women on Boards. Department for Business, Innovation and Skills.

Eagly, A.H. (1987). Sex Differences in Social Behavior: A Social-Role Interpretation. Hillsdale, NJ: Lawrence Erlbaum.

Eagly, A.H. and Johnson, B.T. (1990). Gender and Leadership Style: A Meta-analysis. Psychological Bulletin, 108, pp. 233-56.

Eagly, A.H., Karau, S.J. and Makhijani, M.G. (1995). Gender and the Effectiveness of leaders: A Meta-analysis, Psychological Bulletin, 117, pp. 125-45.

Earley, P. and Mosakowski, E. (2000). Creating Hybrid Team Cultures: An Empirical Test of Transnational Team Functioning. Academy of Management Journal, 43(1), pp. 26-49.

Erhardt, N., Werbel, J. and Shrader, C. (2003). Board of Directors Diversity and Firm Financial Performance. Corporate Governance: An International Review, 11(2), pp. 102-11. 
Erkut, S., Kramer, V.W. and Konrad, A.M. (2008). Critical Mass: Does the Number of Women on a Corporate Board Make a Difference? In S. Vinnicombe, V. Singh, R. Burke, D. Bilimoria and M. and Huse (eds), Women on Corporate Boards of Directors: International Research and Practice. Cheltenham: Edward Elgar, pp. 350-66.

European Commission (2012). Women in Economic Decision-Making in the EU: Progress Report. European Commission, Directorate-General for Justice.

Farrell, K. and Hersch, P.L. (2005). Additions to Corporate Boards: The Effect of Gender. Journal of Corporate Finance, 11(1-2), pp. 85-106.

Fondas, N. and Sassalos, S. (2000). A Different Voice in the Boardroom: How the Presence of Women Directors Affects Board Influence over Management. Global Focus, 12, pp. 13-22.

Forbes, D.P. and Milliken, F.J. (1999). Cognition and Corporate Governance: Understanding Boards of Directors as Strategic Decision-Making Groups. Academy of Management Review, 24, pp. 489-505.

Gul, F.A., Srinidhi, B. and Ng, A.C. (2011). Does Board Gender Diversity Improve the Informativeness of Stock Prices? Journal of Accounting and Economics, 51(3), pp. 314-38.

Groysberg, B. and Bell, D. (2013). Dysfunction in the Boardroom. Harvard Business Review, 91, pp. 89-97.

Grosvold, J. and Brammer, S.J. (2010). National Institutional Systems as Antecedents of Female Board Representation: An Empirical Study. Corporate Governance: An International Review, 19(2), pp. 116-35.

Hambrick, D.C. (2007). Upper Echelons Theory: An Update. Academy of Management Review, 32(2), pp. 334-43.

Hambrick, D.C. and Mason, P.A. (1984). Upper Echelons: The Organization as a Reflection of its Top Managers. Academy of Management Review, 9(2), pp. 193-206.

Heidrick and Struggles (2013). Towards Dynamic Governance 2014 - European Corporate Governance Report.

Hewlett, S.A. (2002). Executive Women and the Myth of Having it All. Harvard Business Review, 80(4), pp. 66-73.

Hewlett, S.A. and Luce, C.B. (2005). Off Ramps and on Ramps. Harvard Business Review, 83(3), pp. $43-54$. 
Hillman, A., Cannella, A. and Paetzold, R. (2000). The Resource Dependence Role of Corporate Directors: Strategic Adaptation of Board Composition in Response to Environmental Change. Journal of Management Studies, 37, pp. 235-55.

Hillman, A.J., Cannella, A.A. and Harris, I.C. (2002). Women and Racial Minorities in the Boardroom: How Do Directors Differ? Journal of Management, 28(6), pp. 747-63.

Huse, M. and Solberg, A.G. (2006). Gender-Related Boardroom Dynamics: How Women Make and Can Make Contributions on Corporate Boards. Women in Management Review, 21(2), pp. 113 30.

Ibarra, H. (1992). Homophily and Differential Returns: Sex Differences in Network Structure and Access in an Advertising Firm. Administrative Science Quarterly, 37, pp. $422-47$.

. (1993). Personal Networks of Women and Minorities in Management: A Conceptual Framework. Academy of Management Review, 18, pp. 56-87.

Ibrahim, N.A. and Angelidis, J.P. (1994). Effect of Board Members' Gender on Corporate Social Responsiveness Orientation. Journal of Applied Business Research, 10(1), pp. 35-40.

Ingley, C. and Van der Walt, N. (2005). Do Board Processes Influence Director and Board Performance? Statutory and Performance Implications. Corporate Governance: An International Review, 13, pp. 632-53.

Kanter, R.M. (1977). Men and Women of the Corporation. New York: Basic Books.

Konrad, A.M. and Kramer, V.W. (2006). How Many Women Do Boards Need? Harvard Business Review, 84(12), pp. 12-22.

Lau, D. and Murnighan, J. (1998). Demographic Diversity and Faultiness: The Compositional Dynamic of Organizational Groups. Academy of Management Review, 23(2), pp. 325-40.

Letendre, L. (2004). The Dynamics of the Boardroom. Academy of Management Executive, 18(1), pp. $101-4$.

Maitland, A. (2010). Addressing the Global Gender Gap. Raconteur on Women Mean Business, supplement distributed with The Times, 30 November.

McKinsey (2007). Women Matter: Gender Diversity: A Corporate Performance Driver. London: McKinsey \& Company.

Minguez-Vera, A. and Martin, A. (2011). Gender and Management on Spanish SMEs: An Empirical Analysis. International Journal of Human Resource Management, 22, pp. 2852-73. 
Nielsen, S. and Huse, M. (2010). Women Directors' Contribution to Board Decision-Making and Strategic Involvement: The Role of Equality Perception. European Management Review, 7(3), pp. 16-29.

O’Donnell, S. and Kennedy, S. (2011). Women Controlling Consumer Spending Sparse among Central Bankers. Bloomberg News, 25 July.

Pan, Y. and Sparks, J.R. (2012). Predictors, Consequence, and Measurement of Ethical Judgments: Review and Meta-analysis. Journal of Business Research, 65, pp. 84-91.

Pathan, S. and Faff, R. (2013). Does Board Structure in Banks Really Affect Their Performance? Journal of Banking and Finance, 37, pp. 1573-89.

Pfeffer, J. and Salancik, G.R. (1978). The External Control of Organizations: A Resource Dependence Perspective. New York: Harper \& Row.

Phipps, S.A. and Burton, P.S. (1998). What's Mine is Yours? The Influence of Male and Female Incomes on Patterns of Household Expenditure. Economica, 65, pp. 599-613.

Post, C. and Byron, K. (2014). Women on Boards and Firm Financial Performance: A Meta-analysis. Academy of Management Journal, published online before print, November.

Powell, G.N. (1999). Handbook of Gender and Works. Thousand Oaks, CA: Sage.

Rose, C. (2007). Does Female Board Representation Influence Firm Performance? The Danish Evidence. Corporate Governance: An International Review, 15, pp. 404-13.

Rosener, J.B. (1990). Ways Women Lead. Harvard Business Review, 68(6), pp. 119-25.

—. (1995). America's Competitive Secret: Utilizing Women as a Management Strategy. New York: Oxford University Press.

Rost, K. and Osterloh, M. (2010). Opening the Black Box of Upper Echelons: Expertise and Gender as Drivers of Poor Information Processing During the Financial Crisis. Corporate Governance: An International Review, 18(3), pp. 212-33.

Ryan, M.K. and Haslam, S.A. (2005). The Glass Cliff: Evidence that Women are Over-represented in Precarious Leadership Positions. British Journal of Management, 16(2), pp. 81-90.

. (2007). Glass Cliffs: Exploring the Dynamics Surrounding the Appointment of Women to Precarious Leadership Positions. Academy of Management Review, 32(2), pp. 549-72. 
Shrader, C.B., Blackburn, V.B. and Iles, P. (1997). Women in Management and Firm Financial Performance: An Exploratory Study. Journal of Managerial Issues, 9, pp. 355-72.

Sheridan, A. and Milgate, G. (2005). Accessing Board Positions: A Comparison of Female and Male Board Members' Views. Corporate Governance: An International Review, 13(6), pp. 847-55.

Singh, V., Terjesen, S. and Vinnicombe, S. (2008). Newly Appointed Directors in the Boardroom: How Do Women and Men Differ? European Management Journal, 26, pp. 48-58.

Smith, J., 2000. Do Women Hold Other Women Back? The Guardian, 5 October.

Srinidhi, B., Gul, F.A. and Tsui, J.S.L. (2011). Female Directors and Earnings Quality. Contemporary Accounting Research, 28(5), pp. 1610-44.

Terjesen, S., Couto, E.B. and Francisco, P.M. (2015). Does the Presence of Independent and Female Directors Impact Firm Performance? A Multi-country Study of Board Diversity. Journal of Management \& Governance, published online 13 January.

Terjesen, S. and Singh, V. (2008). Female Presence on Corporate Boards: A Multi-country Study of Environmental Context. Journal of Business Ethics, 83(1), pp. 55-63.

Torchia, M., Calabro, A. and Huse, M. (2011). Women Directors on Corporate Boards: From Tokenism to Critical Mass. Journal of Business Ethics, 102(2), pp. 299-317.

Virtanen, A. (2012). Women on the Boards of Listed Companies: Evidence from Finland. Journal of Management and Governance, 16, pp. 571-93.

Wall Street Journal (1986). The Corporate Woman: A Special Report, 24 March.

Wang, J. and Coffey, B.S. (1992). Board Composition and Corporate Philanthropy. Journal of Business Ethics, 11(10), pp. 771-8.

Watson, W.E., Kumar, K. and Michaelsen, L.K. (1993). Cultural Diversity's Impact on Interaction Process and Performance: Comparing Homogeneous and Diverse Task Groups. Academy of Management Journal, 36(3), pp. 590-602.

Wiersema, M.F. and Bantel, K. (1992). Top Management Demography and Corporate Strategic Change. Academy of Management Journal, 35(1), pp. 91-121.

Williams, R.J. (2003). Women on Corporate Boards of Directors and Their Influence on Corporate Philanthropy. Journal of Business Ethics, 42(1), pp. 1-10. 